\title{
ЕФЕКТИВНІСТЬ МІКРОДОБРИВ ПРИ ВИРОЩУВАННІ НАСІННИКІВ МОРКВИ
}

\author{
С. І. Корнієнко, О. В. Куц \\ Інститут овочівництва та баштанництва НААН
}

Проведення позакореневих підживлень мікроелементами В+Мо та комплексним мікродобривом «Реаком» забезпечує зростання урожайності насіння моркви на 131 кг/га - 144 кг/га відносно внесення тільки макродобрив, рентабельність $165 \%$ - 166\% сприяє зниженню собівартості насіння до рівня 67,6 грн./кг - 67,9 грн./кг.

мікродобриво, морква, урожайність, якість насіння, рентабельність, собівартість насіння.

Вступ. Новим високопродуктивним сортам овочевих рослин властивий інтенсивний обмін речовин, який потребує достатньої забезпеченості усіма елементами живлення, включаючи мікроелементи. Дефіцит мікроелементів викликаний ще і тим, що різко скоротилося застосування органічних добрив, які були основним джерелом надходження мікроелементів до грунту. Ефективність внесення мікродобрив при вирощуванні моркви на продовольчі цілі відмічалася в дослідженнях В. А. Борисова [1], Т. А. Магалашвілі [2], Т. А. Кунавина [3], Л. В. Мамонової [4], А. І. Фатєєва, С. Ю. Булигіна [5], проведених в різних грунтово-кліматичних зонах України, Росії, країн СНД. У дослідженнях Воронезького сільськогосподарського інституту вивчали вплив на урожайність насіння мікроелементів, що були внесені під маточники [6]. Досліджень 3 використання мікродобрив на насінниках столових коренеплодів не проводилося.

Також не розкрито питання визначення економічного ефекту внесення мікродобрив. Деякі вчені вказують, що при отриманні невисоких приростів урожайності сільськогосподарських культур від внесення мікродобрив, на рівні $5 \%-7$ \%, відмічається несуттєве зростання економічної ефективності та рентабельності. В більшості досліджень [7] застосування мікроелементів разом з мінеральними добривами при їх внесенні в грунт, обробці насіння та позакореневих підживленнях дозволяють отримувати рентабельність внесення мікродобрив на рівні $50 \%-130 \%$. Але отримують і доволі високу рентабельність, особливо при використанні мікроелементів на бідних за поживним складом грунтах. Так, за даними Рак М. В. [8] на дерновопідзолистих грунтах Білорусії використання мікродобрив забезпечує рентабельність $98 \%-415 \%$.

(C) С. І. Корнієнко, О. В. Куц. 2012. ISSN 0582-5075. Селекція і насінництво. 2012. Випуск 102. 
Мета дослідження - визначити вплив позакореневих підживлень мікроелементами на фоні внесення оптимальних доз мінеральних добрив на насіннєву продуктивність моркви; встановити економічну ефективність застосування мікродобрив.

Методика проведення досліду. Наукові дослідження проводилися на чорноземі типовому малогумусному важкосуглинковому (вміст гумусу $-4,3 \%$; рухомого фосфору -119 мг; обмінного калію - 180 мг; легкогідролізуємого азоту - 126 мг/кг грунту; вміст у витяжці ацетатного буферу цинку $-2,2$ мг/кг - 2,3 мг/кг; марганцю - 39,0 мг/кг - 63,0 мг/кг; міді - 0,4 мг/кг - 0,5 мг/кг; кобальту 1,4 мг/кг - 2,1 мг/кг грунту) в умовах лівобережного Лісостепу України протягом 2007-2009 pp. у лабораторії агрохімії та аналітичних вимірювань Інституту овочівництва і баштанництва НААН.

Дослід двофакторний: фактор А - внесення мікродобрив на маточних посівах; фактор В - внесення мікродобрив на насінниках. По фактору А в досліді два варіанти: вирощування маточників на фоні внесення оптимальної дози мінеральних добрив врозкид $\left(\mathrm{N}_{90} \mathrm{P}_{90} \mathrm{~K}_{90}\right)$ та на фоні сумісного застосування макро- та мікродобрив (два позакореневих підживлення мікроелементами $\mathrm{Mo}+\mathrm{Zn}+\mathrm{B}$ у фази початку утворення коренеплоду та під час активного наростання коренеплоду). Використання мікроелементів проводилося на фоні застосування під насінники оптимальних доз мінеральних добрив $\mathrm{N}_{45} \mathrm{P}_{45} \mathrm{~K}_{45}$. Перше позакореневе підживлення мікроелементами на насінниках проводили в фазу відростання квітконосів, а друге - перед цвітінням. У досліді використовувалося попарне та сумісне внесення цинку, бору та молібдену та комплексного мікродобрива «Реаком». Для позакореневого підживлення застосовували розчини наступної концентрації: борна кислота та сульфат цинку - 0,1\%; молібденовокислий амоній - 0,05 \% (за діючою речовиною); мікродобриво «Реаком» 3 нормою 8 л/га. Норма витрати робочої рідини -400 л/га.

У досліді застосовували загальноприйняту технологію вирощування насіння моркви в богарних умовах лісостепової зони Лівобережжя України. Сорт моркви - Яскрава.

Результати досліджень. Встановлено, що в середньому за 20062009 рр. використання мікродобрив в системі удобрення маточників та насінників моркви сприяє істотному збільшенню урожайності насіння (табл. 1); прирости урожайності при цьому коливалися в межах 64 кг/га - 144 кг/га. Найбільш ефективним є внесення в два строки (фаза відростання квітконоса та перед цвітінням) комплексного мікродобрива «Реаком» та суміші В+Мо, що на фоні вирощування маточників з застосуванням тільки $\mathrm{N}_{90} \mathrm{P}_{90} \mathrm{~K}_{90}$ забезпечує зростання урожайності насіння відповідно на 144 кг/га та 131 кг/га, на фоні сумісного використання при вирощуванні маточників макрота мікродобрив - відповідно на 143 кг/га та 141 кг/га. Використання цинку в сумішах для позакореневого підживлення не забезпечувало істотного зростання урожайності насіння моркви, що може бути обумовлене достатньою забезпеченістю чорнозему типового рухомими сполуками цинку та зменшеним споживанням даного мікроелементу насінниками моркви. 
Внесення мікродобрив позитивно впливало на збільшення середньої маси 1000 насінин моркви (табл. 2). Так, на фоні без внесення мікроелементів при вирощуванні маточників даний показник збільшувався з 1,57 г на контрольному варіанті до рівня 1,90 г - 2,10 г за внесення мікроелементів у вигляді двох позакореневих підживлень. На фоні застосування мікродобрив під маточники проведення позакореневих підживлень збільшувало масу 1000 насінин до рівня 1,97 г - 2,13 г за значення даного показнику на контрольному варіанті 1,80 г. Найбільша маса насіння $(2,10$ г - 2,13 г) відмічається при застосуванні підживлень комплексним мікродобривом «Реаком».

Таблиця 1

Вплив позакореневих підживлень мікроелементами на урожайність насіння моркви, кг/га (середнє за 2007-2009 рр.)

\begin{tabular}{|c|c|c|c|c|}
\hline \multirow{2}{*}{\multicolumn{2}{|c|}{$\begin{array}{l}\text { Підживлення насінників } \\
\text { (фактор В) }\end{array}$}} & \multicolumn{2}{|c|}{ Удобрення маточників } & \multirow{3}{*}{$\begin{array}{c}\text { Середні } \\
\text { значення по } \\
\text { фактору В } \\
400 \\
\end{array}$} \\
\hline & & \multirow{2}{*}{$\begin{array}{c}\mathrm{N}_{90} \mathrm{P}_{90} \mathrm{~K}_{90} \\
\text { врозкид }\end{array}$} & \multirow{2}{*}{$\begin{array}{c}\begin{array}{c}\mathrm{N}_{90} \mathrm{P}_{90} \mathrm{~K}_{90}+ \\
\text { мікроелементи }\end{array} \\
435 \\
\end{array}$} & \\
\hline \multirow{5}{*}{ 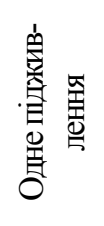 } & $\mathrm{N}_{45} \mathrm{P}_{45} \mathrm{~K}_{45}($ фон $)$ & & & \\
\hline & $\Phi \mathrm{OH}+\mathrm{Zn}+\mathrm{B}$ & 429 & 531 & 480 \\
\hline & Фон $+\mathrm{Zn}+\mathrm{Mo}$ & 430 & 519 & 478 \\
\hline & $\Phi \mathrm{OH}+\mathrm{B}+\mathrm{Mo}$ & 447 & 526 & 487 \\
\hline & $\Phi \mathrm{OH}+\mathrm{Zn}+\mathrm{B}+\mathrm{Mo}$ & 472 & 542 & 507 \\
\hline \multirow{5}{*}{ 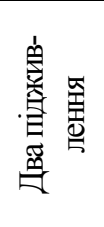 } & $\Phi \mathrm{OH}+\mathrm{Zn}+\mathrm{B}$ & 484 & 525 & 505 \\
\hline & Фон $+\mathrm{Zn}+\mathrm{Mo}$ & 475 & 565 & 520 \\
\hline & $\Phi \mathrm{OH}+\mathrm{B}+\mathrm{Mo}$ & 496 & 578 & 537 \\
\hline & $\Phi \mathrm{OH}+\mathrm{Zn}+\mathrm{B}+\mathrm{Mo}$ & 458 & 553 & 506 \\
\hline & Фон + «Реаком» & 509 & 576 & 543 \\
\hline \multicolumn{2}{|c|}{ Середні значення по фактору А } & 457 & 535 & \\
\hline \multicolumn{2}{|c|}{$\begin{array}{r}\mathrm{HIP}_{0,95} \text { за роками: фактор А } \\
\text { фактор Б } \\
\text { фактор АБ }\end{array}$} & & & $\begin{array}{l}38 ; 45 ; 27 \\
52 ; 61 ; 34 \\
61 ; 66 ; 47\end{array}$ \\
\hline
\end{tabular}

Енергія проростання та лабораторна схожість насіння моркви за використання мікродобрив істотно не змінювалися відносно фонового внесення локально $\mathrm{N}_{45} \mathrm{P}_{45} \mathrm{~K}_{45}$. Так, в середньому по досліду енергія проростання насіння коливалася в межах $63 \%-75 \%$, лабораторна схожість $-81 \%-89 \%$. На фоні вирощування маточників без мікродобрив відмічається позитивна тенденція збільшення значень даних показників за використання позакореневих підживлень сумішами $\mathrm{Zn}+\mathrm{M}, \mathrm{B}+\mathrm{Mo}$ та мікродобрива «Реаком».

У цілому, мікродобрива мають позитивний вплив на посівні якості насіння, обумовлюючи збільшення маси насінини, тенденцію до підвищення енергії проростання та лабораторної схожості. 
Вплив мікродобрив на якість насіння моркви (середнє за 2007-2009 рр.)

\begin{tabular}{|c|c|c|c|}
\hline \multirow[b]{2}{*}{$\begin{array}{c}\text { Підживлення насінників } \\
\text { мікродобривами }\end{array}$} & \multicolumn{3}{|c|}{ Показники якості насіння } \\
\hline & $\begin{array}{l}\text { маса } 1000 \\
\text { насінин, г }\end{array}$ & $\begin{array}{c}\text { енергія } \\
\text { проростання, } \\
\% \\
\end{array}$ & $\begin{array}{l}\text { лабораторна } \\
\text { схожість, \% }\end{array}$ \\
\hline \multicolumn{4}{|c|}{ Вирощування маточників з використання тільки NPK } \\
\hline $\mathrm{N}_{45} \mathrm{P}_{45} \mathrm{~K}_{45}$ (фон) & 1,57 & 63,0 & 81,0 \\
\hline $\mathrm{N}_{45} \mathrm{P}_{45} \mathrm{~K}_{45}+\mathrm{Zn}+\mathrm{B}$ & 2,07 & 64,0 & 81,0 \\
\hline $\mathrm{N}_{45} \mathrm{P}_{45} \mathrm{~K}_{45}+\mathrm{Zn}+\mathrm{Mo}$ & 1,96 & 72,0 & 88,0 \\
\hline $\mathrm{N}_{45} \mathrm{P}_{45} \mathrm{~K}_{45}+\mathrm{B}+\mathrm{Mo}$ & 2,00 & 69,0 & 86,0 \\
\hline $\mathrm{N}_{45} \mathrm{P}_{45} \mathrm{~K}_{45}+\mathrm{Zn}+\mathrm{B}+\mathrm{Mo}$ & 1,90 & 67,0 & 84,0 \\
\hline $\mathrm{N}_{45} \mathrm{P}_{45} \mathrm{~K}_{45}+$ Реаком & 2,10 & 72,0 & 87,0 \\
\hline \multicolumn{4}{|c|}{$\begin{array}{c}\text { Вирощування маточників з сумісним застосуванням макро- та } \\
\text { мікродобрив }\end{array}$} \\
\hline $\mathrm{N}_{45} \mathrm{P}_{45} \mathrm{~K}_{45}($ фон $)$ & 1,80 & 74,0 & 85,0 \\
\hline $\mathrm{N}_{45} \mathrm{P}_{45} \mathrm{~K}_{45}+\mathrm{Zn}+\mathrm{B}$ & 1,97 & 71,0 & 86,0 \\
\hline $\mathrm{N}_{45} \mathrm{P}_{45} \mathrm{~K}_{45}+\mathrm{Zn}+\mathrm{Mo}$ & 2,00 & 73,0 & 87,0 \\
\hline $\mathrm{N}_{45} \mathrm{P}_{45} \mathrm{~K}_{45}+\mathrm{B}+\mathrm{Mo}$ & 2,03 & 75,0 & 89,0 \\
\hline $\mathrm{N}_{45} \mathrm{P}_{45} \mathrm{~K}_{45}+\mathrm{Zn}+\mathrm{B}+\mathrm{Mo}$ & 2,10 & 68,0 & 82,0 \\
\hline $\mathrm{N}_{45} \mathrm{P}_{45} \mathrm{~K}_{45}+$ Реаком & 2,13 & 68,0 & 88,0 \\
\hline $\mathrm{HIP}_{0,95}$ за роками & 0,$11 ; 0,17 ; 0,22$ & 5,$6 ; 6,1 ; 6,3$ & 7,$8 ; 8,1 ; 7,5$ \\
\hline
\end{tabular}

При використанні позакореневих підживлень мікроелементами при вирощуванні насіння моркви прибуток коливався в межах 56830 грн./га - 64990 грн./га, тоді як на фонових варіантах прибуток становив 36270 грн./га - 44370 грн./га (табл. 3). Збільшення урожайності насіння та незначне зростання виробничих витрат на вирощування маточників та насінників моркви зменшує собівартість продукції. За застосування тільки макродобрив собівартість насіння моркви складала 78,0 грн./кг - 80,6 грн./кг, за використанн позакореневих підживлень - 67,6 грн./кг -71,8 грн./га. Рентабельність внесення мікродобрив становила 1515 - 166\%, тоді як на варіантах з використанням тільки мінеральних добрив $1235-131 \%$.

Тобто, при виробництві насіння моркви найкращі економічні показники забезпечує проведення підживлень сумішшю В+Мо та мікродобрива «Реаком».

Висновки. Застосування по фону внесення $\mathrm{N}_{45} \mathrm{P}_{45} \mathrm{~K}_{45}$ позакореневих підживлень мікроелементами В+Мо та комплексним мікродобривом «Реаком» забезпечує збільшення урожайності насіння моркви на 131 кг/га 144 кг/га відносно фону; при цьому рівень рентабельності становив 165\% $166 \%$, собівартість насіння зменшується до 67,6 грн./кг - 67,9 грн./кг. 
Економічна ефективність використання мікродобрив при вирощуванні насіння моркви (середнє за 2007-2009 рр.)

\begin{tabular}{|c|c|c|c|c|c|}
\hline \multirow[b]{2}{*}{$\begin{array}{l}\text { Удобрення } \\
\text { насінників }\end{array}$} & \multicolumn{5}{|c|}{ Економічні показники } \\
\hline & $\begin{array}{c}\text { урожай- } \\
\text { ність } \\
\text { насіння, } \\
\text { кг/га }\end{array}$ & $\begin{array}{c}\text { витрати } \\
\text { вирощу- } \\
\text { вання, } \\
\text { грн./га }\end{array}$ & $\begin{array}{l}\text { прибу- } \\
\text { ток, } \\
\text { грн./га }\end{array}$ & $\begin{array}{c}\text { повна } \\
\text { собівар- } \\
\text { тість } 1 \text { кг } \\
\text { насіння, } \\
\text { грн. }\end{array}$ & $\begin{array}{c}\text { рентабе- } \\
\text { льність } \\
\text { виробни- } \\
\text { цтва, } \\
\%\end{array}$ \\
\hline \multicolumn{6}{|c|}{ Вирощування маточників при внесенні тільки $\mathrm{N}_{90} \mathrm{P}_{90} \mathrm{~K}_{90}$} \\
\hline $\begin{array}{l}\mathrm{N}_{45} \mathrm{P}_{45} \mathrm{~K}_{45} \\
\text { (локально) }\end{array}$ & 365 & 29430 & 36270 & 80,6 & 123 \\
\hline \multicolumn{6}{|c|}{ Вирощування маточників при внесенні $\mathrm{N}_{90} \mathrm{P}_{90} \mathrm{~K}_{90}+$ в два строки $\mathrm{Zn}+\mathrm{B}+\mathrm{Mo}$} \\
\hline $\begin{array}{l}\mathrm{N}_{45} \mathrm{P}_{45} \mathrm{~K}_{45} \\
\text { (локально) }\end{array}$ & 435 & 33930 & 44370 & 78,0 & 131 \\
\hline \multicolumn{6}{|c|}{ Позакореневі підживлення в два строки на фоні $\mathrm{N}_{45} \mathrm{P}_{45} \mathrm{~K}_{45}$} \\
\hline $\mathrm{Zn}+\mathrm{B}$ & 525 & 37670 & 56830 & 71,8 & 151 \\
\hline $\mathrm{Zn}+\mathrm{Mo}$ & 565 & 38700 & 63000 & 68,5 & 163 \\
\hline $\mathrm{B}+\mathrm{Mo}$ & 578 & 39050 & 64990 & 67,6 & 166 \\
\hline $\mathrm{Zn}+\mathrm{B}+\mathrm{Mo}$ & 553 & 38970 & 60570 & 70,5 & 155 \\
\hline $\begin{array}{l}\text { Мікродобриво } \\
\text { «Реаком» }\end{array}$ & 576 & 39100 & 64580 & 67,9 & 165 \\
\hline
\end{tabular}

\section{Список використаних джерел:}

1. Борисов В. А. Удобрения овощных культур / В. А. Борисов. - М.: Колос, 1978. - $207 \mathrm{c}$.

2. Магалашвили Т. А. Эффективность сева дражироваными семенами лука, моркови и столовой свеклы в поливных условиях Нижней Картли: автореф. дис. на соискание уч. степени канд. с.-х. наук / Т. А. Магалашвили. Тбилиси, 1966. -25 с.

3. Кунавин Т. А. Эффективность дражирования семян моркови и лука в условиях Целиноградской области: автореф. дис. на соискание уч. степени канд. с.-х. наук: спец. 06.01.06 «Овощеводство» / Т. А. Кунавин. Ташкент, 1974. - 23 с.

4. Мамонова Л. В. Применение комплексонов и комплексонатов под белокочанную капусту и столовые корнеплоды на дерново-подзолистой почве: автореф. дис. на соискание уч. степени канд. с.-х. наук: спец. 06.01.06 «Овощеводство» / Л. В. Мамонова. - М., 1992. - 23 с.

5. Фатєєв А. І. Мікроелементи в сільському господарстві / А. I. Фатєєв, С. Ю. Булигін. - Харків, 2001.

6. Алексеева А. М. Влияние микроэлементов бора, марганца, кобальта и молибдена на урожай, качество и лёжкость корнеплодов моркови / А. М. Алексеева, И. Н. Рассказов // Селекция, семеноводство и агротехники овощных культур в Центрально-Черноземной зоне : научные труды 
Воронежского с.-х. института. - Воронеж, 1976. - Т. 85. - С. 5-7.

7. Юркин С. Н. Повышение коэффициента использования удобрений: обзор информация / С. Н. Юркин, З. К. Благовещенская, А. А. Пименов. - М., 1976. $-78 \mathrm{c}$.

8. Рак М. В. Эффективность применения микроудобрений в республике Беларусь / М. В. Рак // Агрохімія та грунтознавство на шляху до сталого розвитку України: міжвідомчий темат. наук. збірник. - Харків, 2002. T. 3. - C. 277-278.

Проведение внекорневых подкормок микроэлементами В+Мо и комплексного микроудобрения «Реаком» обеспечивает увеличение урожайности семян моркови на 131 кг/га - 144 кг/га относительно внесения только макроудобрений, рентабельность $165 \%$ - 166\% обеспечивает снижение себестоимости семян до уровня 67,6 грн./кг - 67,9 грн./кг.

The holding of foliar-applied micronutrients B+Mo and integrated micronutrients «Reacom» provides increase in the yield of seeds of carrots at $131 \mathrm{~kg} / \mathrm{ha}$ $-144 \mathrm{~kg} / \mathrm{ha}$ for the only fertilizers, profitability of $165 \%-166 \%$, to reduce production costs of seeds to the level of $67,6 \mathrm{UAH} / \mathrm{kg}-67,9 \mathrm{UAH} . / \mathrm{kg}$. 